\title{
Characteristics of pediatric and adult cases with open globe injury and factors affecting visual outcomes: A retrospective analysis of 294 cases from Turkey
}

\author{
Işıl Kutlutürk Karagöz, M.D.,, Esin Söğütlü Sarı, M.D., ${ }^{2}$ Anıl Kubaloğlu, M.D., ${ }^{3}$ Ahmet Elbay, M.D., ${ }^{4}$ \\ Ümit Çallı, M.D., ${ }^{1}$ David P Pinero, M.D., ${ }^{5}$ Yusuf Özertürk, M.D., ${ }^{6}$ Titap Yazıcıoğlu, M.D. ${ }^{6}$
}

\begin{abstract}
${ }^{1}$ Department of Ophthalmology, Ümraniye Training and Research Hospital, İstanbul-Turkey
${ }^{2}$ Department of Ophthalmology, Balıkesir University Faculty of Medicine, Balıkesir-Turkey

${ }^{3}$ Department of Ophthalmology, Etiler Dünya Eye Hospital, İstanbul-Turkey

${ }^{4}$ Department of Ophthalmology, Bezmialem Vakıf University Faculty of Medicine, İstanbul-Turkey

${ }^{5}$ Department of Optics, Pharmacology and Anatomy, University of Alicante, Alicante-Spain

${ }^{6}$ Department of Ophthalmology, Kartal Dr. Lütfi Kırdar Training and Research Hospital, İstanbul-Turkey
\end{abstract}

\begin{abstract}
BACKGROUND: This study aimed to evaluate I-year follow-up results of cases that were diagnosed with open globe injury (OGI), to compare trauma-related characteristics between pediatric and adult cases, and to determine risk factors for a poor final visual acuity.

METHODS: This study enrolled 294 cases that met the OGI definition and were followed up for at least I year. Demographic and clinical features regarding ocular trauma were recorded. The cases were divided into two groups according to age: pediatric ( $\leq 16$ years) and adult ( $>16$ years) groups.

RESULTS: Children were exposed to accidents that led to OGI mostly at home, whereas adults were exposed to such accidents mostly in the office. Penetrating injuries were more common in children than in adults, and injuries most commonly occurred owing to spiky objects. Zone I injuries were most frequent in both children and adults. The frequency of high-grade injuries increased with age. Foreign body injuries and multiple surgeries were more common in adults than in children. There was no difference between the two age groups based on ocular trauma score (OTS) and visual acuity. OTS predicted the need for multiple surgeries. In the adult group, age, multiple surgeries, and initial visual acuity were significant risk factors for the final visual acuity that was achieved.
\end{abstract}

CONCLUSION: OGI causes and risk factors for poor final visual outcomes differ in adults and children. The knowledge of these differences is crucial for taking adequate preventive measures and decreasing morbidity.

Keywords: Eye injuries; penetrating eye injuries; trauma.

\section{INTRODUCTION}

The annual incidence of hospital admissions because of ocular trauma ranges between 8 and 15 per 100000 individuals, and $>10 \%$ of these patients develop vision loss. ${ }^{\left[{ }^{1,2]}\right.}$ Approximately 1.6 million people are estimated to have vision loss, 2.3 million people have bilateral visual impairment, and 19 million people have unilateral visual impairment owing to ocular trauma worldwide. Accidents leading to ocular trauma peak in the childhood and at geriatric age. ${ }^{[l]}$ The majority (up to $90 \%$ ) of these accidents are preventable. ${ }^{[2,3]}$ The detection and definition of the causes and characteristics of trauma enables clinicians to take the most adequate preventive measures. However, causes of ocular trauma and types

\footnotetext{
Cite this article as: Kutlutürk Karagöz I, Söğütlü Sarı E, Kubaloğlu A, Elbay A, Çallı Ü, Pinero DP, et al. Characteristics of pediatric and adult cases with open globe injury and factors affecting visual outcomes: A retrospective analysis of 294 cases from Turkey. Ulus Travma Acil Cerrahi Derg 2018;24:31-8

Address for correspondence: Işıl Kutlutürk Karagöz, M.D.

Ümraniye Eğitim ve Araştırma Hastanesi, Göz Hastalıkları Kliniği, İstanbul, Turkey.

Tel: +90 216-6321818 E-mail: slkutluturk@gmail.com

Ulus Travma Acil Cerrahi Derg 2018;24(I):3I-38 DOI: 10.5505/tjtes.2017.03607 Submitted: 08.1I.2016 Accepted: 12.05.2017

Copyright 2018 Turkish Association of Trauma and Emergency Surgery
} 
of injury may differ in time because of the implementation of preventive strategies, changes in working practices, and life style changes. ${ }^{[1]}$ For all this, descriptive epidemiological studies on ocular trauma and its management in different regions of the world are necessary.

Open globe injury (OGI) is defined as a full-thickness injury of the sclera and cornea, which threatens vision and may result in blindness. ${ }^{[4,5]}$ Compared with closed eye injuries, open injuries have poorer prognosis. ${ }^{[6-8]}$ OGls, which represent a substantial proportion of ocular traumas, accounts for a substantial proportion of ocular trauma-related hospital expenditure $(>60 \%)$ and supposes a significant financial burden. ${ }^{[9]}$

The estimation of final visual acuity just after OGI is important for both patients and physicians who deal with its treatment. Thus, the precise definition of factors that influence the final visual acuity and knowing the characteristics of trauma according to geographical regions and characteristics of a population would be beneficial. This study aimed to evaluate I-year follow-up results of cases diagnosed with OGI at our hospital, to compare trauma-related characteristics between pediatric and adult cases, and to assess risk factors that influence final visual acuity.

\section{MATERIALS AND METHODS}

\section{Patients}

Computerized data of cases with ocular trauma who were admitted to the Emergency Ophthalmology Clinic of Dr. Lütfü Kırdar Kartal Training and Research Hospital between January 2000 and December 20I I were retrospectively evaluated. IN this study, 294 patients aged between I and 85 years and who met the OGI definition and were followed up for at least I year were included.

\section{Parameters Evaluated}

Patient data regarding age, sex, time between injury and hospital admission, date of injury, follow-up duration, place of injury, types of objects that caused injury, presence of foreign body, type of trauma, location (zone), severity (grade), sites of trauma in the globe such as eyelid, primary surgery, additional surgery (multiple surgery), additional surgical procedures (keratoplasty, anterior chamber wash out, pupiloplasty, lens aspiration, phacoemulsification, anterior vitrectomy, scleral fixation, intravitreal injection, or vitreoretinal surgery), initial and final visual acuity, and ocular trauma score (OTS) of each patient were recorded.

Ocular traumas of patients included in the study were defined as penetration, perforation, intraocular foreign body (IOFB), or rupture according to the Birmingham Eye Trauma Terminology and Ocular Trauma Classification (OTC) group guidelines. ${ }^{[10]}$ The term "penetration" was used for patients with a single laceration detected on the eye wall, the term "perforation" was used for patients with two full-thickness lacerations (entrance and exit) caused by the same agent, and the term "rupture" was used for patients with full-thickness injuries in the eye wall caused by a blunt object. Patients with a foreign body in the eye were considered as IOFB. Localization of injury was defined according to the OTC group guidelines: injuries only limited to the cornea were considered as zone I, those in the area covering the corneoscleral limbus to a $5-\mathrm{mm}$ point posterior on the sclera were considered as zone II, and those extending their full thickness into the sclera at $>5 \mathrm{~mm}$ posterior to the corneoscleral limbus were considered as zone III. The severity of a trauma was categorized into the following four grades according to Eagling criteria: grade I involving the cornea and anterior sclera with and without prolapse of the iris, grade 2 involving concurrent anterior segment and lens injury, grade 3 involving posterior segment injury and vitreous loss, and grade 4 involving extensive anterior and posterior injuries. ${ }^{[I]}$ The OTS score for each patient was calculated based on initial visual acuity, rupture, endophthalmitis, perforating injury, retinal detachment, and afferent pupillary defect parameters. ${ }^{[12]}$

All decimal visual acuity values recorded in the medical history of each patient were converted into the logMAR scale for statistical analyses. Three different groups of patients were defined according to the logMAR visual acuity obtained: $\leq 0.3,0.3-1.0$, and $>1.0$. A visual acuity of $>1.0$ was considered to be poor, whereas that of $\leq 0.3$ was considered to be good. Besides a subdivision of the sample according to the level of vision, two additional groups were defined according to age: pediatric group comprising patients aged $\leq 16$ years and adult group comprising patients aged $>16$ years.

All cases underwent a primary repair of OGI in the shortest time after admission (first $24 \mathrm{~h}$ ). Patients with a corneal trauma and lamellar laceration without spontaneous leakage were followed up after fitting a therapeutic contact lens and prescribing topical antibiotic therapy. For cases that required a surgical procedure for repairing an injury, topical antibiotherapy was administered until surgery. In these cases, systemic antibiotherapy was not prescribed, only receiving intrachamber antibiotherapy intraoperatively and a subconjunctival injection of a combination of antibiotic and steroid postoperatively. Intravitreal antibiotherapy was administered to cases that were suspected of endophthalmitis, detected during the postoperative follow-up. For these cases, topical treatment was continued for at least I month after the surgery, and they underwent detailed ophthalmological examination at regular intervals. Additional surgeries were performed if required during the follow-up.

\section{Statistical Analysis}

Data were analyzed using the Statistical Package for the Social Sciences (SPSS Inc., Chicago, IL, USA) version I5.00 software. 
In addition to descriptive statistics (mean, standard deviation, and frequencies), crosstab table and chi-square test were used to assess the significance of differences in percentages among the groups. For quantitative variables, two group comparisons were performed using Student's t-test for unpaired data that were normally distributed (checked with KolmogorovSmirnov test), whereas Mann-Whitney test was used for data that were not normally distributed. Moreover, the predicting factors for the final visual acuity were identified using logistic regression analysis. For all cases, the level of significance was considered to be $p$ values of $<0.05$.

\section{RESULTS}

Of 294 study participants, I I 8 (40.2\%) were included in the pediatric group (mean age, $7.67 \pm 4.15$ years) and 176 subjects $(59.8 \%)$ were included in the adult group (mean age, $36.85 \pm 15.00$ years). The majority of accidents occurred at home, and most patients were admitted to the hospital within the first $24 \mathrm{~h}$. The general characteristics of the pediatric and adult groups are presented in Table I.

Differences were detected between the pediatric and adult groups in terms of sex, place of accident, type of trauma, and

Table I. General characteristics of cases with ocular trauma

\begin{tabular}{|c|c|c|c|c|c|}
\hline & \multicolumn{2}{|c|}{$\begin{array}{l}\text { Pediatric } \\
\text { group } \\
(n=\mid 18)\end{array}$} & \multicolumn{2}{|c|}{$\begin{array}{l}\text { Adult } \\
\text { group } \\
(n=176)\end{array}$} & \multirow[t]{2}{*}{$\mathbf{p}$} \\
\hline & $\mathbf{n}$ & $\%$ & $\mathbf{n}$ & $\%$ & \\
\hline \multicolumn{6}{|l|}{ Sex } \\
\hline Male & 69 & 58.5 & 151 & 85.8 & $<.001$ \\
\hline Female & 49 & 41.5 & 25 & 14.2 & \\
\hline \multicolumn{6}{|l|}{ Place of accident } \\
\hline Home & 95 & 80.5 & 64 & 36.4 & $<.001$ \\
\hline Office/school & 7 & 5.9 & 69 & 39.2 & \\
\hline Street/traffic accident & 16 & 13.6 & 43 & 24.4 & \\
\hline \multicolumn{6}{|l|}{ Type of trauma ${ }^{a}$} \\
\hline Rupture & 26 & 22.2 & 60 & 34.3 & .027 \\
\hline Penetrating & 91 & 77.8 & 115 & 65.7 & \\
\hline \multicolumn{6}{|l|}{ Cause of trauma } \\
\hline Spiky objects & 41 & 34.7 & 43 & 24.4 & .005 \\
\hline Glass & 19 & 16.1 & II & 6.8 & \\
\hline Stone & 13 & 11.0 & 14 & 8.0 & \\
\hline Metal & 8 & 6.8 & 27 & 15.3 & \\
\hline Wood & 8 & 6.8 & 21 & 11.9 & \\
\hline Assault & 7 & 5.9 & 12 & 6.8 & \\
\hline Traffic accident & 5 & 4.2 & 21 & 11.9 & \\
\hline Other & 17 & 14.4 & 26 & 14.8 & \\
\hline
\end{tabular}

${ }^{2}$ Two perforating-type traumas were not included in the analysis. cause of trauma. The ratio of male:female patient was significantly higher in the adult group than in the pediatric group. In the pediatric group, home was the most common place of accident, whereas in the adult group, office was the most common place of accidents. Penetrating injuries were more prevalent in the pediatric group than in the adult group. Regarding the cause of trauma, Sharp pointed objects, glass, and stones were the most frequent causes of trauma in the pediatric group, whereas sharp pointed objects, metal, wood, and traffic accidents were the most common causes of trauma in the adult group. Final visual acuity was $>1.0$ after an injury caused by wood in all pediatric cases and was $>1.0$ after traffic accidents in one of the highest percentage of adult cases (66.7\%). Although visual acuity was observed to be more frequently better than $1.0 \log$ MAR after traumas accompanied by foreign body in both adult and pediatric groups $(74.1 \%$ and $66.7 \%$ in adults and children, respectively), the presence of foreign body did not have any significant effect on postoperative visual acuity $(p>0.05)$. Trauma-related characteristics are summarized in Table 2.

Zone I traumas were most frequent in both the groups, although differences among the age groups in the distribution of traumas according to zones did not reach statistical significance. Grade 2, 3, and 4 traumas were more frequent in the adult group than in the pediatric group, whereas the frequency of grade I injury was higher in the pediatric group than in the adult group. The presence of foreign body was significantly more frequent in the adult group than in the pediatric group. Regarding the surgical management of cases, the requirement of multiple surgical procedures was more frequent in the adult group than in the pediatric group. Cornea involvement was the most common site of trauma in both the groups, followed by iris involvement and lens injury. Eyelid involvement, traumatic cataract development, traumatic injury of lens, intravitreal hemorrhage, and retinal injury were more common in the adult group than in the pediatric group. There were no differences between the groups with regard to distribution of cases according to OTS. The characteristics of trauma according to OTS in the pediatric and adult groups are shown in Tables 3 and 4, respectively. Although an increase was observed in penetrating injuries in the adult group as OTS progressed to 5 (i.e., improved), a decrease was determined in rupture injuries. In contrast, the distribution of types of trauma as a function of OTS was found to be more similar in the pediatric group. The frequency of multiple surgery increased in the adult group as OTS worsened (i.e., progressed to I) $(\mathrm{p}<0.00 \mathrm{I})$. Likewise, the frequency of multiple surgeries was higher in the pediatric group as OTS progressed to I (rate was the highest for OTS of 2). In the adult group, the frequency of the presence of foreign body increased as OTS progressed to $4(p=0.003)$. In the pediatric group, no difference was found between different values of OTS in terms of the presence of foreign body. Both initial and final visual acuity worsened as OTS worsened (progressed to I) in both the groups. 
Table 2. Trauma-related characteristics of the cases

\begin{tabular}{|c|c|c|c|c|c|}
\hline & \multicolumn{2}{|c|}{$\begin{array}{l}\text { Pediatric group } \\
\quad(n=118)\end{array}$} & \multicolumn{2}{|c|}{$\begin{array}{l}\text { Adult group } \\
(n=176)\end{array}$} & \multirow[t]{2}{*}{$\mathbf{p}$} \\
\hline & $\mathbf{n}$ & $\%$ & $\mathbf{n}$ & $\%$ & \\
\hline \multicolumn{6}{|l|}{ Distribution according to the zones } \\
\hline Zone I & 83 & 70.3 & 120 & 69.0 & .692 \\
\hline Zone II & 21 & 17.8 & 37 & 21.3 & \\
\hline Zone III & 14 & 11.9 & 17 & 9.8 & \\
\hline \multicolumn{6}{|l|}{ Distribution according to the grades } \\
\hline Grade I & 75 & 64.1 & 81 & 46.3 & .025 \\
\hline Grade 2 & 19 & 16.2 & 42 & 23.9 & \\
\hline Grade 3 & 19 & 16.2 & 37 & 21.0 & \\
\hline Grade 4 & 5 & 4.2 & 16 & 9.1 & \\
\hline Presence of foreign body & 6 & 5.1 & 27 & 15.3 & .006 \\
\hline \multicolumn{6}{|l|}{ Surgery ${ }^{a}$} \\
\hline Primary & 86 & 73.5 & 94 & 54.7 & .001 \\
\hline Multiple & 31 & 26.5 & 78 & 45.3 & \\
\hline \multicolumn{6}{|l|}{ Ocular trauma scores } \\
\hline I & 40 & 33.9 & 61 & 34.7 & .839 \\
\hline 2 & 45 & 38.1 & 64 & 36.4 & \\
\hline 3 & 26 & 22.0 & 38 & 21.6 & \\
\hline 4 & 7 & 5.9 & II & 6.3 & \\
\hline 5 & 0 & 0.0 & 2 & I.I & \\
\hline \multicolumn{6}{|l|}{ Involved site } \\
\hline Cornea involvement & 106 & 89.8 & 160 & 90.9 & .757 \\
\hline Iris involvement & 66 & 55.9 & 79 & 44.9 & .063 \\
\hline Lens injury & 33 & 28.0 & 78 & 44.3 & .005 \\
\hline Presence of hyphema & 31 & 26.3 & 55 & 31.3 & .358 \\
\hline Conjunctiva involvement & 30 & 25.4 & 46 & 26.1 & .891 \\
\hline Sclera involvement & 29 & 24.6 & 45 & 25.6 & .848 \\
\hline Development of traumatic cataract & 28 & 23.7 & 69 & 39.2 & .006 \\
\hline Limbal involvement & 24 & 20.3 & 48 & 27.3 & .175 \\
\hline Vitreous involvement & 21 & 17.8 & 36 & 20.5 & .572 \\
\hline Presence of iridodialysis & 14 & 11.9 & 28 & 15.9 & .331 \\
\hline Presence of intravitreal hemorrhage & 9 & 7.6 & 31 & 17.6 & .014 \\
\hline Retinal injury & 8 & 6.8 & 32 & 18.2 & .005 \\
\hline Eye-lid involvement & 5 & 4.2 & 24 & 13.6 & .008 \\
\hline Optic disc involvement & 5 & 4.2 & 13 & 7.4 & .270 \\
\hline
\end{tabular}

The surgical procedures performed are summarized in Table 5. The frequency of vitreoretinal surgery was higher in the adult group than in the pediatric group. The frequencies of other procedures were found to be similar in both the groups.

Logistic regression analysis was performed to determine the factors that had an influence on the final visual acuity achieved in the adult group. A prediction model was created including, as potential influencing factors, age, sex, eyelid, cornea, conjunctiva, sclera, limbal, iris, optic disc involvement, presence of hyphema and iridodialysis, development of traumatic cataract, lens injury, presence of intravitreal hemorrhage, retinal injury, presence of foreign body, initial visual acuity, OTS, zone, grade, and surgery, and requirement or not of multiple surgery. Age 
Table 3. Characteristics of trauma according to ocular trauma scores in the pediatric group

\begin{tabular}{|c|c|c|c|c|c|c|c|c|c|}
\hline & \multicolumn{8}{|c|}{ Ocular trauma scores } & \multirow[t]{3}{*}{$\mathbf{p}$} \\
\hline & \multicolumn{2}{|c|}{$\mathbf{I}$} & \multicolumn{2}{|c|}{2} & \multicolumn{2}{|c|}{3} & \multicolumn{2}{|c|}{4} & \\
\hline & $\mathbf{n}$ & $\%$ & $\mathbf{n}$ & $\%$ & $\mathbf{n}$ & $\%$ & $\mathbf{n}$ & $\%$ & \\
\hline \multicolumn{10}{|l|}{ Type of trauma } \\
\hline Rupture & 11 & 28.2 & 11 & 24.4 & 4 & 15.4 & 0 & 0.0 & .303 \\
\hline Penetrating & 28 & 71.8 & 34 & 75.6 & 22 & 84.6 & 7 & 100.0 & \\
\hline Presence of foreign body & 0 & 0.0 & 2 & 4.4 & 3 & 11.5 & 1 & 14.3 & .130 \\
\hline \multicolumn{10}{|l|}{ Surgery } \\
\hline Primary & 30 & 75.0 & 27 & 60.0 & 22 & 88.0 & 7 & 100.0 & .024 \\
\hline Multiple & 10 & 25.0 & 18 & 40.0 & 3 & 12.0 & 0 & 0.0 & \\
\hline \multicolumn{10}{|l|}{ Initial logMAR visual acuity } \\
\hline$\leq 0.3$ & I & 2.5 & 0 & 0.0 & 0 & 0.0 & 5 & 71.4 & $<.001$ \\
\hline $0.3-1.0$ & 0 & 0.0 & $\mathrm{I}$ & 2.2 & 5 & 19.2 & 0 & 0.0 & \\
\hline$>1.0$ & 39 & 97.5 & 44 & 97.8 & 21 & 80.8 & 2 & 28.6 & \\
\hline \multicolumn{10}{|c|}{ Final (I year follow-up) logMAR visual acuity } \\
\hline$\leq 0.3$ & 6 & 15.0 & 5 & 11.1 & 7 & 26.9 & 5 & 71.4 & $<.001$ \\
\hline $0.3-1.0$ & 1 & 2.5 & 10 & 22.2 & 7 & 26.9 & 0 & 0.0 & \\
\hline$>1.0$ & 33 & 82.5 & 30 & 66.7 & 12 & 46.2 & 2 & 28.6 & \\
\hline
\end{tabular}

logMar: Logarithm of the minimum angle of resolution.

Table 4. Characteristics of trauma according to ocular trauma scores in the adult group

\begin{tabular}{|c|c|c|c|c|c|c|c|c|c|c|c|}
\hline & \multicolumn{10}{|c|}{ Ocular trauma scores } & \multirow[t]{3}{*}{$\mathbf{p}$} \\
\hline & \multicolumn{2}{|c|}{ I } & \multicolumn{2}{|c|}{2} & \multicolumn{2}{|c|}{3} & \multicolumn{2}{|c|}{4} & \multicolumn{2}{|r|}{5} & \\
\hline & $\mathbf{n}$ & $\%$ & $\mathbf{n}$ & $\%$ & $\mathbf{n}$ & $\%$ & $\mathbf{n}$ & $\%$ & $\mathbf{n}$ & $\%$ & \\
\hline \multicolumn{12}{|l|}{ Type of trauma } \\
\hline Rupture & 29 & 47.5 & 19 & 30.2 & 8 & 21.1 & 2 & 18.2 & 2 & 100.0 & .010 \\
\hline Penetrating & 32 & 52.5 & 44 & 69.8 & 30 & 78.9 & 9 & 81.8 & 0 & 0.0 & \\
\hline Presence of foreign body & 5 & 8.2 & 10 & 15.6 & 6 & 15.8 & 6 & 54.5 & 0 & 0.0 & .003 \\
\hline \multicolumn{12}{|l|}{ Surgery } \\
\hline Primary & 25 & 41.0 & 29 & 45.3 & 30 & 81.1 & 8 & 100.0 & 2 & 100.0 & $<.001$ \\
\hline Multiple & 36 & 59.0 & 35 & 54.7 & 7 & 18.9 & 0 & 0.0 & 0 & 0.0 & \\
\hline \multicolumn{12}{|l|}{ Initial logMAR visual acuity } \\
\hline$\leq 0.3$ & 0 & 0.0 & 0 & 0.0 & 0 & 0.0 & 9 & 81.8 & 2 & 100.0 & $<.001$ \\
\hline $0.3-1.0$ & 0 & 0.0 & 0 & 0.0 & 19 & 50.0 & 2 & 18.2 & 0 & 0.0 & \\
\hline$>1.0$ & $6 I$ & 100.0 & 64 & 100.0 & 19 & 50.0 & 0 & 0.0 & 0 & 0.0 & \\
\hline \multicolumn{12}{|c|}{ Final (I year follow-up) logMAR visual acuity } \\
\hline$\leq 0.3$ & 0 & 0.0 & 9 & 14.1 & 12 & 31.6 & II & 100.0 & 2 & 100.0 & $<.001$ \\
\hline $0.3-1.0$ & 8 & 13.1 & 17 & 26.6 & 17 & 44.7 & 0 & 0.0 & 0 & 0.0 & \\
\hline$>1.0$ & 53 & 86.9 & 38 & 59.4 & 9 & 23.7 & 0 & 0.0 & 0 & 0.0 & \\
\hline
\end{tabular}

logMar: Logarithm of the minimum angle of resolution.

$(p=0.003 ; O R=1.067 ; 95 \% C l=1.023-1.1 \mid 3)$, multiple surgery $(p=0.015 ; O R=6.443 ; 95 \% C l=I .427-29.083)$, and initial vis- ual acuity $(p=0.009 ; O R=6.735 ; 95 \% C l=I .6 I I-28 . \mid 57)$ were risk factors, whereas eyelid involvement $(p=0.005 ; O R=0.010$; 
Table 5. Surgical procedures

\begin{tabular}{|c|c|c|c|c|c|}
\hline & \multicolumn{2}{|c|}{$\begin{array}{l}\text { Pediatric } \\
\text { group } \\
(n=\mid 18)\end{array}$} & \multicolumn{2}{|c|}{$\begin{array}{l}\text { Adult } \\
\text { group } \\
(n=176)\end{array}$} & \multirow[t]{2}{*}{$\mathbf{p}$} \\
\hline & $\mathbf{n}$ & $\%$ & $\mathbf{n}$ & $\%$ & \\
\hline Penetrating keratoplasty & 15 & 12.7 & 27 & 15.3 & .528 \\
\hline Anterior chamber lavage & 17 & 14.4 & 33 & 18.8 & .331 \\
\hline Pupiloplasty & 12 & 10.2 & 13 & 7.4 & .402 \\
\hline Lens aspiration & 17 & 14.4 & 39 & 22.2 & .097 \\
\hline Phacoemulsification & 10 & 8.5 & 17 & 9.7 & .730 \\
\hline Anterior vitrectomy & 15 & 12.7 & 28 & 15.9 & .447 \\
\hline Scleral fixation & 5 & 4.2 & 8 & 4.5 & .900 \\
\hline Intravitreal injection & 2 & 1.7 & 3 & 1.7 & .995 \\
\hline Vitreoretinal surgery & 3 & 2.5 & 16 & 9.1 & .025 \\
\hline
\end{tabular}

Table 6. Initial and final logMAR visual acuity in the pediatric and adult groups

\begin{tabular}{llll}
\hline $\begin{array}{c}\text { Pediatric } \\
\text { group } \\
(\mathrm{n}=118)\end{array}$ & & $\begin{array}{c}\text { Adult } \\
\text { group } \\
(\mathrm{n}=176)\end{array}$ \\
\cline { 1 - 2 }$\%$ & $\mathrm{n} \%$ \\
\hline
\end{tabular}

Initial logMAR visual

acuity

$\begin{array}{lccccc}\leq 0.3 & 6 & 5.1 & 11 & 6.3 & .116 \\ 0.3-1.0 & 6 & 5.1 & 21 & 11.9 & \\ >1.0 & 106 & 89.8 & 144 & 81.8 & \end{array}$

Final (I year follow-up)

$\log M A R$ visual acuity

\begin{tabular}{lccccc}
$\leq 0.3$ & 23 & 19.5 & 34 & 19.3 & .183 \\
$0.3-1.0$ & 18 & 15.3 & 42 & 23.9 & \\
$>1.0$ & 77 & 65.3 & 100 & 56.8 & \\
\hline
\end{tabular}

logMar: Logarithm of the minimum angle of resolution.

$95 \% \mathrm{Cl}=0.000-0.247)$ was a protecting factor. In the pediatric group, a model was created using the same influencing factors as those in the adult group. Age $(p=0.008 ; O R=0.826$; $95 \% \mathrm{Cl}=0.7 / 8-0.950$ ) was significant as a protecting factor, although no parameter was determined to be a risk factor.

\section{DISCUSSION}

Besides ocular trauma characteristics, including causes, place, mechanism of action, severity, and localization, it is necessary to determine the factors that influence the posttreatment visual acuity to define and initiate the most adequate preventive actions. Many epidemiological studies have reported that ocular trauma is more common among males than among females. ${ }^{[13-19]}$ In our sample, ocular trauma was also more fre- quent in males, with the male:female ratios of $I .4: 1$ and $6: 1$ in the pediatric and adult groups, respectively.

Accidents leading to ocular trauma occurred in office and home among adult cases (39.2\% and $36.4 \%$, respectively), and the frequency in children of home accidents leading to ocular trauma was $80.5 \%$ and school accidents was $5.9 \%$ ( $p<0.00 \mathrm{l}$ ). A study in Qatar evaluated 106 children aged $<16$ years who were admitted to a hospital after ocular injury and reported that $40.6 \%$ of traumas were OGI and that $42.5 \%$ of traumas occurred at home. ${ }^{[16]}$ In addition, similar results were reported by studies in the literature. ${ }^{[|9-2|]} \mathrm{A}$ Chinese study comprising overall age groups reported that the majority of ocular traumas were work related and resulted in substantial loss of vision. ${ }^{[22]}$ According to our outcomes and the results of all these studies, it appears recommendable to take measures at home to protect children from danger, as well as at work, by wearing safety goggles to prevent accidents leading to ocular trauma. Occupational accidents that cause ocular trauma in adults can be substantially prevented by education given within the scope of occupational health and safety and by encouraging the use of eye-protecting devices. ${ }^{[23]}$

Different causes of ocular trauma have been reported, such as stone, wooden and metallic objects, household goods, entertainment objects, and firearm/penetrating/sharp objects. [15,20-24] In the present study, the most frequent causes of ocular trauma were sharp pointed objects (34.7\%), glass ( $16.1 \%)$, and stone $(11.0 \%)$ in the pediatric group and sharp pointed objects (24.4\%), metal (15.3\%), wood (11.9\%), and traffic accident (11.9\%) in the adult group. Final visual acuity was more frequently $>1.0$ logMAR in the pediatric group when injured by wood $(100 \%)$, whereas it was the highest in the adult group when injured after traffic accidents (66.7\%). Although zone I traumas were more frequent in both the pediatric and adult groups ( $70.3 \%$ and $69 \%$, respectively), no difference was determined between the groups in terms of distribution of traumas according to zones.

The rate of serious injuries increases with age. ${ }^{[25]}$ In Italy, a 12-year retrospective evaluation of children aged $<14$ years revealed that hospitalization was required in $3 \%$ of overall ocular traumas. ${ }^{[18]}$ In Greece, the rate of hospitalization owing to ocular trauma in all the age groups in a 9-year period was $7 \% .{ }^{[14]}$ In the present study, although the frequency of grade I injury was higher in the pediatric group than in the adult group, that of grade 2, 3, 4 injuries was higher in the adult group than in the pediatric group. This confirmed the hypothesis that the grade increases with age. The presence of foreign body was also more common in the adult group than in the pediatric group $(15.3 \%$ vs. $5.1 \%$; $p=0.006)$. In in the adult group, the most common cause of injury was metal $(40.7 \%)$, whereas in the pediatric group, the most common cause was sharp pointed objects (33.3\%). Initial visual acuity was most frequently $>1.0$ logMAR in traumas accompanied by foreign body in both the groups $(74.1 \%$ and $66.7 \%$ in the adult 
and pediatric groups, respectively). However, the presence of foreign body did not have an effect on postoperative visual acuity $(p>0.05)$. This result contradicts that of many studies in the literature. This may be because of the small number of patients with IOFB in the study group. ${ }^{[26]}$

Many studies have reported that the cornea and sclera are the most commonly involved areas in open injuries. ${ }^{[8,13,15,16,24,27-29]}$ Likewise, in the present study, cornea involvement owing to trauma was the most prevalent in both the groups, followed by iris involvement and lens injury. Eyelid involvement, traumatic cataract development, traumatic injury of the lens, intravitreal hemorrhage, and retinal injury were more commonly found in the adult group than in the pediatric group. In addition, eyelid involvement $(\mathrm{p}=0.005 ; \mathrm{OR}=0.010 ; 95 \% \mathrm{Cl}=0.000-0.247)$ was a protecting factor. This protective effect may depend on the eyelid blinking activity that prevents globe penetration during trauma. Although studies in the literature have different findings related to eyelid involvement percentage, no clear results have shown the potential risk or protective effect of eyelid involvement, except a study from Israel. In Israel, 118 eyes (II6 patients) with OGI were evaluated in a 10-year period, and eyelid injuries were associated with poor visual outcomes. ${ }^{[29]}$ Despite differences in terms of the severity of trauma and the level of involvement of ocular structures, no difference was found between both the groups in terms of distribution of cases according to OTS. The fact that initial visual acuity is an important component in OTS calculation and the presence of foreign body is not included in such calculation may be factors that account for this finding. In the present study, OTS predicted the final visual acuity, and this prognosis became poorer as OTS worsened in both the pediatric and adult groups.

In our sample, primary surgery was performed in $61.2 \%$ of cases, and multiple surgeries were required in $37.1 \%$ of overall cases. The frequency of multiple surgeries was higher in the adult group than in the pediatric group $(26.5 \%$ vs. $45.3 \%$; $p=0.00 \mathrm{I})$. In addition, the rate of multiple surgeries increased in adults as OTS worsened $(\mathrm{p}<0.00 \mathrm{I})$ and this similarly occurred in children, although the frequency of multiple surgery was higher in cases with OTS of $2(p=0.024)$. According to this, OTS worsening predicts the potential requirement of multiple surgeries.

No significant difference was observed between the pediatric and adult groups in terms of the distribution of final visual acuity. According to all these outcomes and similar to adults, the final visual acuity was poor in our sample of children, although the severity of trauma and the need for multiple surgeries were lower in children than in adults.

Defining risk factors for a poor final visual outcome after ocular trauma is crucial to provide the most adequate information and counseling to patients with these types of traumas. Most studies in the literature reported that an age of $<5$ years or an increased age, eyelid injury, injuries with retrolimbal in- volvement, wound length of $>5 \mathrm{~mm}$, globe rupture, vitreous hemorrhage, retinal detachment, and relative afferent pupillary defect were risk factors for a final best-corrected visual acuity. ${ }^{[7,8,17,29-34]}$ In our study, the risk factor analysis revealed that there was no significant parameter that affected final visual acuity in children, although age was the only protective factor. In adults, age, additional surgical procedure, and initial visual acuity were significant as risk factors.

In conclusion, $\mathrm{OGI}$ is more prevalent among males than among females. In children, majority of accidents leading to OGl occur at home, whereas in adults, majority of accidents occur in office. Penetrating injuries, most of them owing to sharp pointed objects, are more common in children than in adults. Foreign body injuries and multiple surgeries are more common in adults than children, with an increase in the frequency of high-grade injuries with age. OTS can be used to predict the requirement of multiple surgeries. In adults, age, multiple surgeries, and initial visual acuity are significant risk factors for the final visual acuity. To determine the causes and risk factors for $\mathrm{OGI}$, a condition that can result in a serious loss of vision, it is crucial for taking adequate preventive measures and for decreasing morbidity. Education on preventing occupational risks should also include the causes of $O G I$ and the preventive measures to avoid them.

\section{Conflict of interest: None declared.}

\section{REFERENCES}

1. MacEwen CJ. Ocular injuries. J R Coll Surg Edinb 1999;44:317-23.

2. Abbott J, Shah P. The epidemiology and etiology of pediatric ocular trauma. Surv Ophthalmol 2013;58:476-85. [CrossRef]

3. Easterbrook M. Prevention of ocular trauma. Can J Ophthalmol 2009;44:501-3. [CrossRef]

4. Kuhn F, Morris R, Witherspoon CD. Birmingham Eye Trauma Terminology (BETT): terminology and classification of mechanical eye injuries. Ophthalmol Clin North Am 2002;15:139-43. [CrossRef]

5. Schmidt GW, Broman AT, Hindman HB, Grant MP. Vision survival after open globe injury predicted by classification and regression tree analysis. Ophthalmology 2008;115:202-9. [CrossRef]

6. Shah M, Shah S, Khandekar R. Ocular injuries and visual status before and after their management in the tribal areas of Western India: a historical cohort study. Graefes Arch Clin Exp Ophthalmol 2008;246:191-7.

7. Smith AR, O'Hagan SB, Gole GA. Epidemiology of open- and closedglobe trauma presenting to Cairns Base Hospital, Queensland. Clin Exp Ophthalmol 2006;34:252-9. [CrossRef]

8. Soliman MM, Macky TA. Pattern of ocular trauma in Egypt. Graefes Arch Clin Exp Ophthalmol 2008;246:205-12. [CrossRef]

9. Cao H, Li L, Zhang M, Li H. Epidemiology of pediatric ocular trauma in the Chaoshan Region, China, 2001-2010. PLoS One 2013;8:e60844.

10. Pieramici DJ, Sternberg P Jr, Aaberg TM Sr, Bridges WZ Jr, Capone A $\mathrm{Jr}$, Cardillo JA, et al. A system for classifying mechanical injuries of the eye (globe). The Ocular Trauma Classification Group. Am J Ophthalmol 1997;123:820-31. [CrossRef]

11. Eagling EM. Perforating injuries of the eye. Br J Ophthalmol 1976;60:732-6. [CrossRef] 
12. Kuhn F, Maisiak R, Mann L, Mester V, Morris R, Witherspoon CD. The Ocular Trauma Score (OTS). Ophthalmol Clin North Am 2002;15:163-5. [CrossRef]

13. Oum BS, Lee JS, Han YS. Clinical features of ocular trauma in emergency department. Korean J Ophthalmol 2004;18:70-8. [CrossRef]

14. Mela EK, Dvorak GJ, Mantzouranis GA, Giakoumis AP, Blatsios G, Andrikopoulos GK, et al. Ocular trauma in a Greek population: review of 899 cases resulting in hospitalization. Ophthalmic Epidemiol 2005;12:185-90. [CrossRef]

15. Soylu M, Sizmaz S, Cayli S. Eye injury (ocular trauma) in southern Turkey: epidemiology, ocular survival, and visual outcome. Int Ophthalmol 2010;30:143-8. [CrossRef]

16. Al-Mahdi HS, Bener A, Hashim SP. Clinical pattern of pediatric ocular trauma in fast developing country. Int Emerg Nurs 2011;19:186-91.

17. Cao H, Li L, Zhang M. Epidemiology of patients hospitalized for ocular trauma in the Chaoshan region of China, 2001-2010. PLoS One 2012;7:e48377. [CrossRef]

18. Malagola R, Arrico L, Migliorini R, D’Ambrosio EM, Grenga R. Ocular traumatology in children. A retrospective study. G Chir 2012;33:423-8.

19. Sharifzadeh M, Rahmanikhah E, Nakhaee N. Pattern of pediatric eye injuries in Tehran, Iran. Int Ophthalmol 2013;33:255-9. [CrossRef]

20. Cariello AJ, Moraes NS, Mitne S, Oita CS, Fontes BM, Melo LA Jr. Epidemiological findings of ocular trauma in childhood. Arq Bras Oftalmol 2007;70:271-5. [CrossRef]

21. Serrano JC, Chalela P, Arias JD. Epidemiology of childhood ocular trauma in a northeastern Colombian region. Arch Ophthalmol 2003;121:1439-45.

22. Chang CH, Chen CL, Ho CK, Lai YH, Hu RC, Yen YL. Hospitalized eye injury in a large industrial city of South-Eastern Asia. Graefes Arch Clin Exp Ophthalmol 2008;246:223-8. [CrossRef]

23. Soong TK, Koh A, Subrayan V, Loo AV. Ocular trauma injuries: a 1-year surveillance study in the University of Malaya Medical Centre, Malaysia. 2008. Graefes Arch Clin Exp Ophthalmol 2011;249:1755-60. [CrossRef]
24. Mansouri M, Faghihi H, Hajizadeh F, Rasoulinejad SA, Rajabi MT, Tabatabaey A, et al. Epidemiology of open-globe injuries in Iran: analysis of 2,340 cases in 5 years (report no. 1). Retina 2009;29:1141-9. [CrossRef]

25. Saeed A, Khan I, Dunne O, Stack J, Beatty S. Ocular injury requiring hospitalisation in the south east of Ireland: 2001-2007. Injury 2010;41:86-91.

26. Chiquet C, Zech JC, Denis P, Adeleine P, Trepsat C. Intraocular foreign bodies. Factors influencing final visual outcome. Acta Ophthalmol Scand 1999;77:321-5. [CrossRef]

27. Oner A, Kekec Z, Karakucuk S, Ikizceli I, Sözüer EM. Ocular trauma in Turkey: a 2-year prospective study. Adv Ther 2006;23:274-83. [CrossRef]

28. Fea A, Bosone A, Rolle T, Grignolo FM. Eye injuries in an Italian urban population: report of 10,620 cases admitted to an eye emergency department in Torino. Graefes Arch Clin Exp Ophthalmol 2008;246:175-9.

29. Knyazer B, Bilenko N, Levy J, Lifshitz T, Belfair N, Klemperer I, et al. Open globe eye injury characteristics and prognostic factors in southern Israel: a retrospective epidemiologic review of 10 years experience. Isr Med Assoc J 2013;15:158-62.

30. Bunting H, Stephens D, Mireskandari K. Prediction of visual outcomes after open globe injury in children: a 17-year Canadian experience. J AAPOS 2013;17:43-8. [CrossRef]

31. Han SB, Yu HG. Visual outcome after open globe injury and its predictive factors in Korea. J Trauma 2010;69:E66-72. [CrossRef]

32. Cillino S, Casuccio A, Di Pace F, Pillitteri F, Cillino G. A five-year retrospective study of the epidemiological characteristics and visual outcomes of patients hospitalized for ocular trauma in a Mediterranean area. BMC Ophthalmol 2008;8:6. [CrossRef]

33. Khatry SK, Lewis AE, Schein OD, Thapa MD, Pradhan EK, Katz J. The epidemiology of ocular trauma in rural Nepal. Br J Ophthalmol 2004;88:456-60. [CrossRef]

34. Tok O, Tok L, Ozkaya D, Eraslan E, Ornek F, Bardak Y. Epidemiological characteristics and visual outcome after open globe injuries in children. J AAPOS 2011;15:556-61. [CrossRef]

\section{ORIJINAL ÇALIŞMA - ÖZET}

\section{Açık göz yaralanmalarının çocuk ve erişkin yaş gruplarındaki karakteristikleri ve görsel prognozu etkileyen risk faktörleri: Türkiye'den 294 olgunun geriye dönük analizi \\ Dr. Işıl Kutlutürk Karagöz,, ${ }^{1}$ Dr. Esin Söğütlü Sarı, ${ }^{2}$ Dr. Anıl Kubaloğlu, ${ }^{3}$ Dr. Ahmet Elbay, ${ }^{4}$ Dr. Ümit Çallı, ${ }^{1}$ Dr. David P Pinero, ${ }^{5}$ Dr. Yusuf Özertürk, ${ }^{6}$ Dr. Titap Yazıcıoğlu ${ }^{6}$}

1Ümraniye Eğitim ve Araştırma Hastanesi, Göz Hastalıkları Kliniği, İstanbul
Balıkesir Üniversitesi Tıp Fakültesi, Göz Hastalıkları Anabilim Dalı, Balıkesir
${ }^{3}$ Etiler Dünya Göz Hatanesi, Göz Hastalıkları Kliniği, İstanbul
${ }^{4}$ Bezmialem Vakıf Üniversitesi Tıp Fakültesi, Göz Hastalıkları Anabilim Dalı, İstanbul
${ }^{5}$ Alicante Üniversitesi, Optik, Farmakoloji ve Anatomi Anabilim Dalı, Alicante, İspanya
${ }^{6}$ Kartal Dr. Lütfi Kırdar Eğitim ve Araştırma Hastanesi, Göz Hastalıkları Kliniği, İstanbu

AMAÇ: Açık göz yaralanması (AGY) olgularının karakteristiklerini ve kötü görsel prognoz için risk faktörlerini çocuk ve erişkin yaş gruplarında incelemek.

GEREÇ VE YÖNTEM: En az bir ylık takibi olan 294 AGY olgusu çalı̧maya alındı. Göz travması ile ilgili demografik ve klinik özellikler kaydedildi. Olgular yaşlarına göre çocuk ( $\leq 16$ yıl) ve erişkin (>16 yıl) olmak üzere iki gruba ayrıldı.

BULGULAR: Açık göz yaralanmasına neden olan kazalara çocukların çoğunlukla ev ortamında maruz kaldığı görülürken erişkinlerin iş ortamlarında maruz kaldığı görüldü. Penetran göz yaralanmalarının çocuklarda daha sık olduğu ve sıkıkla sivri uçlu cisimlerle oluştuğu saptandı. Her iki grupta da Zon I yaralanmaların daha sık olduğu görüldü. Yükssek evre yaralanmaların sıklığının yaş ile birlikte arttığı saptandı. Yabancı cisim yaralanmaları ve birden fazla ameliyat gerekliliği erişkin grupta daha fazlaydı. Yaş grupları arasında oküler travma skoru (OTS) ve görme keskinliği açısından fark yoktu. OTS, birden fazla ameliyat ihtiyacı ile ilişkili bulundu. Erişkin yaş grubunda, yaş, birden fazla ameliyat olmak ve başlangıç görme keskinliği sonuç görme keskinliği için önemli risk faktörleri olarak bulundu.

TARTIŞMA: Hem AGY nedenleri hem de kötü görsel prognoz için risk faktörleri, erişkin ve çocuk yaş gruplarında farklılıklar göstermektedir. Bu farklılıkların bilinmesi önleyici tedbirlerin alınmasında ve morbiditenin azaltılması konusunda önemli olabilir.

Anahtar sözcükler: Göz yaralanmaları; penetran göz yaralanmaları; travma.

Ulus Travma Acil Cerrahi Derg 20I8;24(I):3I-38 doi: 10.5505/tjtes.2017.03607 